Article

\title{
Phenotypic Characterization of Rhodococcus equi Biofilm Grown In Vitro and Inhibiting and Dissolving Activity of Azithromycin/Rifampicin Treatment
}

\author{
Elisa Rampacci ${ }^{1, *(1)}$, Maria Luisa Marenzoni ${ }^{1}$, Stefano Giovagnoli ${ }^{2}\left(\mathbb{D}\right.$, Fabrizio Passamonti $^{1}{ }^{(D)}$, \\ Mauro Coletti ${ }^{1}$ and Donatella Pietrella ${ }^{3}$ (D) \\ 1 Department of Veterinary Medicine, University of Perugia, Via San Costanzo 4, 06126 Perugia, Italy; \\ marialuisa.marenzoni@unipg.it (M.L.M.); fabrizio.passamonti@unipg.it (F.P.); mauro.coletti@unipg.it (M.C.) \\ 2 Department of Pharmaceutical Sciences, University of Perugia, Via del Liceo 1, 06123 Perugia, Italy; \\ stefano.giovagnoli@unipg.it \\ 3 Department of Pharmaceutical Sciences, Biochemical Sciences and Health Section, University of Perugia, \\ Via del Giochetto, 06122 Perugia, Italy; donatella.pietrella@unipg.it \\ * Correspondence: elisa.rampacci@gmail.com
}

Received: 8 November 2019; Accepted: 3 December 2019; Published: 4 December 2019

\begin{abstract}
Microbial biofilm has been implicated in a wide range of chronic infections. In spite of the fact that Rhodococcus equi is a recognized cause of chronic disease in animals and humans, few studies have focused on the sessile phenotype of R. equi. The aim of this research was to phenotypically characterize the biofilm development of $R$. equi and its answerability for hypo-responsiveness to macrolides and rifampicin. Biofilm formation is initiated by bacterial adhesion to the surface. In this work, the ability of $R$. equi to adhere to the surface of human lung epithelial cells was detected by a fluorometric adhesion test performed on 40 clinical isolates. Subsequently, the capability of R. equi to produce biofilm was investigated by colorimetric, fluorescence and scanning electron microscopy analysis, revealing a general slow growth of rhodococcal biofilm and different sessile phenotypes among field isolates, some also including filamented bacteria. Azithromycin treatment produced a higher long-term inhibition and dissolution of R. equi biofilms than rifampicin, while the two antibiotics combined boosted the anti-biofilm effect in a statistically significant manner, although this was not equally effective for all $R$. equi isolates. Increasing the MIC concentrations of drugs tenfold alone and in combination did not completely eradicate pre-formed R. equi biofilms, while a rifampicin-resistant isolate produced an exceptionally abundant extracellular matrix. These results have strengthened the hypothesis that biofilm production may occur as an antibiotic tolerance system in R. equi, potentially determining persistence and, eventually, chronic infection.
\end{abstract}

Keywords: biofilm formation; respiratory infection; biofilm dissolution; biofilm inhibition; scanning electron microscopy; fluorescence analysis

\section{Introduction}

Biofilm formation is considered one of the underlying reasons for antibiotic treatment failure [1]. Facultative intracellular bacteria causing chronic infections, such as Mycobacterium tuberculosis, are able to embed themselves within an extracellular matrix-enclosed biofilm containing free mycolic acids [2], which is believed to be highly resistant to antibiotics. Recently, Rhodococcus species have been added to the list of biofilm forming organisms [3] and are members of the phylogenetic group Mycolata together with the genera Mycobacterium, Corynebacterium, and Nocardia due to the mycolic acids found in their cell walls. Rhodococcus equi is a facultative intracellular pathogen that is well-known as the main etiological agent of subacute/chronic pneumonia in foals and is recognized as a human opportunistic 
pathogen, responsible for chronic zoonosis, in addition to being a telluric germ that is widespread in the environment. Recently, an increased number of reports have noted the worldwide spread of R. equi human infections, especially among immunocompromised subjects [4-10]. Eighty percent of cases show pulmonary involvement [11], suggesting airborne transmission [12], particularly due to exposure to domesticated horses [13,14]. Indeed, most R. equi strains that cause pneumonia in foals and many strains that cause pneumonia in humans carry the plasmidic vap $A^{+}$gene [15]. However, since the variant plasmid markers $\operatorname{tra}^{+} / \mathrm{vap}^{-} B^{+}, \operatorname{tra}^{+} / \mathrm{vap} A B^{-}$have been identified in non-horse hosts intended for human consumption as well as in humans, food-borne transmission seems to be probable $[16,17]$. Increased concern about $R$. equi infections is ascribed to misdiagnosis as tuberculosis due to the similarities in clinical features, acid-fast staining, and bacterial wall composition with $M$. tuberculosis $[7,18]$. Notwithstanding increasing evidence of public health risk, little is known about the ability of $R$. equi to establish a sessile microbial community.

Substantial strain-to-strain variation in growth rates and biofilm formation was observed among high and low passage clinical isolates [19], and one of the few published works concerning in vitro $R$. equi biofilm production reported that $63 \%$ of the collected equine clinical samples were populated by biofilm-forming strains at $24 \mathrm{~h}$ of incubation [20]. Additionally, R. equi isolates causing bacteremia in humans were found to be able to form thick microbial biofilms on the surface of polyurethane catheters [3].

Adhesion of bacteria to host tissue is the first step in the development of biofilm-related infectious diseases [21]. Electron microscopy studies have suggested that facultative intracellular infective microorganisms such as mycobacterial cells may be able to adhere to the lung alveolar epithelium [22] and thus spend part of their pulmonary life-cycle as an extracellular pathogen, potentially forming antibiotic resistant biofilms responsible for disease reactivation. To date, $R$. equi pathogenesis has scarcely been characterized, and appropriate treatments for sessile rhodococcosis have not been established, although the association of a macrolide with rifampicin (RIF) seems effective against planktonic bacteria [23]. The treatment outcome of bacterial biofilms is often unpredictable. Indeed, while appropriate antimicrobial treatments can lead to biofilm eradication [24], sub-effective drug levels can promote biofilm growth [25].

In this work, in order to provide clues supporting the relevance of putative biofilm-related processes in R. equi disease, an in vitro kinetic analysis of R. equi biofilm formation and adhesion to basal human alveolar epithelial cells was carried out. Several equine $R$. equi clinical isolates, including an ATCC cell line, were compared. Moreover, to investigate R. equi biofilm formation as a resistance factor, the dissolution and inhibition capacity of the spray-dried azithromycin (AZM) and RIF powder combination, found previously to be effective on a planktonic strain [26], was measured in comparison with using the drugs alone.

\section{Results}

\subsection{Biofilm Formation and Cellular Adhesion of Fluorescein-Labelled Rhodococcus equi}

After bacteriological and molecular identification and detection of the virulence plasmid VapA in $100 \%$ (39/39) of the clinical isolates, field bacteria (Re1-Re39) and R. equi ATCC 33701 were tested for their capability to form biofilm. Figure 1A summarizes the growth of rhodococcal biofilms, measured at $24 \mathrm{~h}$ intervals. No bacterium was described as a strong biofilm producer, i.e., producing more than fourfold higher biofilm mass than the negative control. Nine out of the 40 rhodococci $(22.5 \%)$, ATCC 33701, Re1, Re4, Re6, Re9, Re19, Re24, Re30, and Re36, formed moderate biofilms at $96 \mathrm{~h}$. Only one bacterium, the isolate Re9, was classified as an early moderate producer at $72 \mathrm{~h}$. At least $48 \mathrm{~h}$ of incubation proved to be necessary to confirm all bacteria as biofilm forming organisms through crystal violet biofilm assay.

In an effort to investigate the capacity of bacteria to adhere to the biotic surface, a fluorescence-based adhesion assay was performed on pulmonary alveolar epithelium. Figure 1B shows the percentage of 
adhered bacteria. All fluorescein isothiocyanate (FITC)-labelled bacteria proved to be able to adhere to the pulmonary basal alveolar epithelium, suggesting the presence of potential cellular receptors involved in R. equi adhesion. R. equi adhered to A459 monolayers over a percentage range of between $1.5 \%$ and $5 \%$ of the initial inoculum (equal to $1 \times 10^{7}$ bacterial cells). Accordingly, the number of adherent bacteria, obtained by interpolating the medium intense fluorescence of each isolate with the relative calibration curve, was included in the range of $(1.5-5) \times 10^{5}$ bacterial cells. The average percentage adhesion of the positive control Staphylococcus aureus ATCC 25923 was equal to $1.3 \% \pm 0.2 \%$. Adhesion percentages of all tested rhodococci and the coefficients of determination $\left(\mathrm{r}^{2}\right)$ associated with the calibration curves plotted for all bacteria in each biological replicate are reported in Supplementary Table S1. The coefficients of determination $\left(\mathrm{r}^{2}\right)$ of the replicates were within the reasonable value range of 0.98-0.9999. A statistically significant correlation was found between the adhesion capability and biofilm produced at $96 \mathrm{~h}$ by the Spearman rho test $(p \leq 0.039)$, whereas no statistical significance was observed at 24,48 , and $72 \mathrm{~h}$ of biofilm formation $(p \geq 0.123)$.

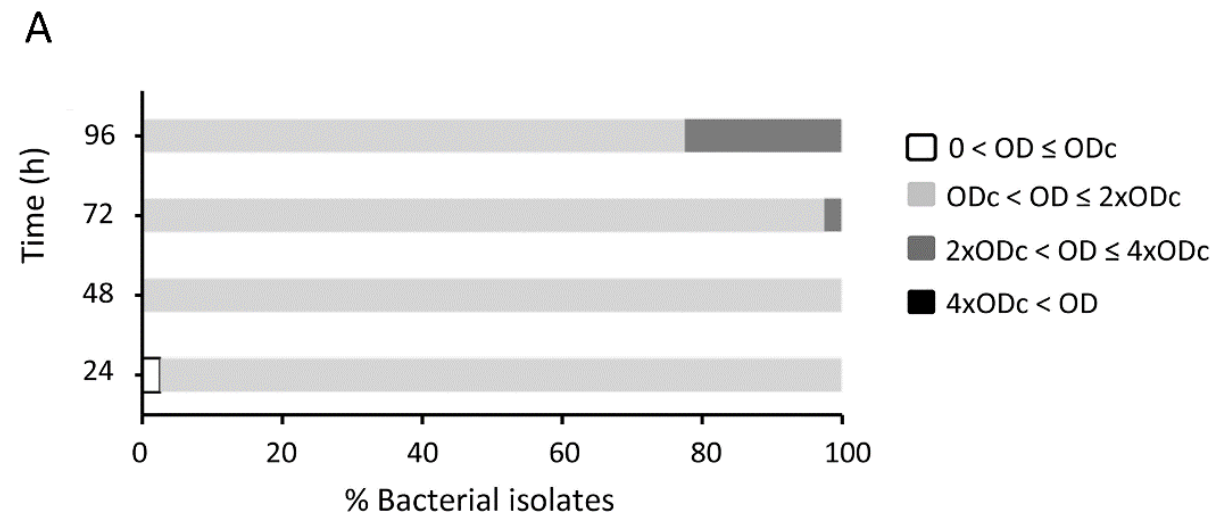

B

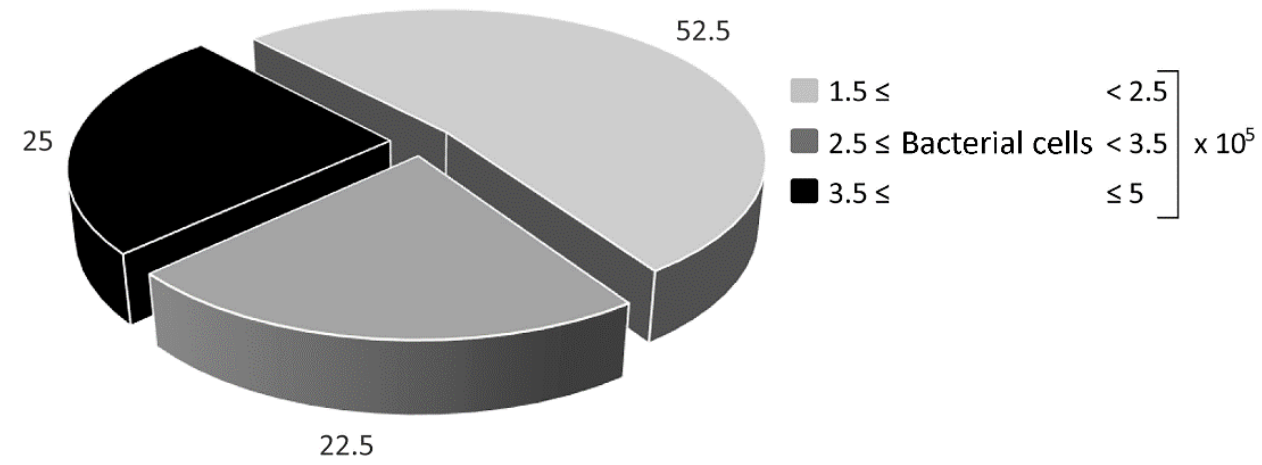

$\%$ Adhered bacterial isolates

Figure 1. Kinetic growth of rhodococcal biofilms and cellular adhesion of fluorescent rhodococci. (A) Growth of rhodococcal biofilm measured at $24 \mathrm{~h}$ intervals and categorized as a non-biofilm producer $0 \leq \mathrm{OD} \leq \mathrm{ODc}$ (negative control absorbance value); weak biofilm producer ODc $<\mathrm{OD} \leq 2 \times \mathrm{ODc}$; moderate biofilm producer $2 \times$ ODc $<$ OD $\leq 4 \times$ ODc; and strong biofilm producer $4 \times$ ODc $<$ OD. (B) Percentage of adhered bacteria.

\subsection{Minimum Inhibitory Concentration of Antibiotics against Rhodococcus equi Isolates}

In this study, the first-line drugs AZM and RIF were tested alone and in the exact drug molar ratio 2:1 for the AZM/RIF combination, which was previously found to be synergistically bactericidal against planktonic R. equi and effective against a R. equi-infected intracellular model long-term [26], to investigate their minimum inhibitory concentration (MIC) against planktonic $R$. equi and their anti-biofilm properties. As a result of the increased solubility and dispersibility of the excipient-free 
spray-dried formulation, no organic solvent was used so as to test the drug itself and the combination in an exact drug molar ratio. All bacteria were susceptible to the antimicrobials tested, except for Re4 and Re2-moderate and weak biofilm producers, respectively - which were resistant to RIF. The AZM/RIF 2:1 MIC halved compared to RIF, the most potent compound, against 16/40 rhodococci, including 5/9 moderate biofilm producers: ATCC 33701, Re1, Re9, Re19, and Re24. The MIC values for all the tested treatments are summarized in Table 1.

Table 1. Minimum inhibitory concentrations of azithromycin (AZM), rifampicin (RIF), and the AZM/RIF combination at a 2:1 ratio against Rhodococcus equi.

\begin{tabular}{|c|c|c|c|c|c|c|c|}
\hline Bacteria & AZM & RIF & AZM/RIF 2:1 & Bacteria & AZM & RIF & AZM/RIF 2:1 \\
\hline $\operatorname{Re} 1$ & 2 & 0.125 & $0.125 / 0.06$ & $\operatorname{Re} 21$ & 2 & 0.06 & $0.125 / 0.06$ \\
\hline $\operatorname{Re} 2$ & 1 & 64 & $1 / 0.5$ & $\operatorname{Re} 22$ & 1 & 0.125 & $0.25 / 0.125$ \\
\hline Re3 & 2 & 0.06 & $0.06 / 0.03$ & $\operatorname{Re} 23$ & 2 & 0.25 & $0.25 / 0.125$ \\
\hline $\operatorname{Re} 4$ & 1 & 128 & $1.0 / 0.5$ & $\operatorname{Re} 24$ & 1 & 0.125 & $0.125 / 0.06$ \\
\hline Re5 & 1 & 0.25 & $0.25 / 0.125$ & $\operatorname{Re} 25$ & 1 & 0.125 & $0.25 / 0.125$ \\
\hline $\operatorname{Re} 6$ & 1 & 0.125 & $0.25 / 0.125$ & $\operatorname{Re} 26$ & 1 & 0.125 & $0.125 / 0.06$ \\
\hline $\operatorname{Re} 7$ & 1 & 0.03 & $0.06 / 0.03$ & $\operatorname{Re} 27$ & 1 & 0.25 & $0.25 / 0.125$ \\
\hline $\operatorname{Re} 8$ & 1 & 0.06 & $0.06 / 0.03$ & $\operatorname{Re} 28$ & 2 & 0.25 & $0.5 / 0.25$ \\
\hline $\operatorname{Re} 9$ & 1 & 0.25 & $0.25 / 0.125$ & $\operatorname{Re} 29$ & 2 & 0.06 & $0.125 / 0.06$ \\
\hline $\operatorname{Re} 10$ & 2 & 0.06 & $0.125 / 0.06$ & $\operatorname{Re} 30$ & 1 & 0.06 & $0.125 / 0.06$ \\
\hline $\operatorname{Re} 11$ & 1 & 0.25 & $0.25 / 0.125$ & $\operatorname{Re} 31$ & 1 & 0.06 & $0.125 / 0.06$ \\
\hline Re12 & 2 & 0.125 & $0.25 / 0.125$ & $\operatorname{Re} 32$ & 2 & 0.125 & $0.25 / 0.125$ \\
\hline $\operatorname{Re13}$ & 2 & 0.125 & $0.25 / 0.125$ & $\operatorname{Re} 33$ & 1 & 0.06 & $0.125 / 0.06$ \\
\hline $\operatorname{Re14}$ & 2 & 0.25 & $0.25 / 0.125$ & $\operatorname{Re} 34$ & 1 & 0.125 & $0.25 / 0.125$ \\
\hline $\operatorname{Re15}$ & 2 & 0.125 & $0.25 / 0.125$ & Re35 & 1 & 0.06 & $0.125 / 0.06$ \\
\hline $\operatorname{Re} 16$ & 1 & 0.125 & $0.25 / 0.125$ & $\operatorname{Re} 36$ & 1 & 0.03 & $0.06 / 0.03$ \\
\hline $\operatorname{Re17}$ & 1 & 0.25 & $0.25 / 0.125$ & $\operatorname{Re} 37$ & 1 & 0.03 & $0.06 / 0.03$ \\
\hline $\operatorname{Re} 18$ & 2 & 0.015 & $0.03 / 0.015$ & $\operatorname{Re} 38$ & 1 & 0.125 & $0.25 / 0.125$ \\
\hline Re19 & 1 & 0.125 & $0.125 / 0.06$ & Re39 & 2 & 0.25 & $0.25 / 0.125$ \\
\hline $\operatorname{Re} 20$ & 1 & 0.125 & $0.125 / 0.06$ & 33701 & 0.5 & 0.125 & $0.125 / 0.06$ \\
\hline
\end{tabular}

Results are expressed in $\mathrm{mg} / \mathrm{L}$ and represent the mean of three independent experiments performed in triplicate.

\subsection{Long-Term Antimicrobial Prevention of Rhodococcus equi Biofilm}

The antibiotic inhibition of the moderate biofilms produced by R. equi isolates Re1, Re4, Re9, Re19, Re24, and ATCC 33701 was evaluated after $96 \mathrm{~h}$ of incubation by spectrophotometric determination by performing the crystal violet assay.

Treatments consisted of AZM and RIF alone and AZM/RIF 2:1 at the MIC value. Additionally, to thoroughly investigate the potential boosting effect exerted by the drug combination, AZM and RIF were tested alone at the MIC value acquired in combination $\left(\mathrm{MIC}_{\text {in combination }}\right)$.

As detailed in Table 2, AZM demonstrated a dose-dependent efficacy boosted by the combination with RIF. Indeed, AZM at the MIC concentration proved to be the most active long-term antibiotic against $R$. equi biofilm $(p \leq 0.029)$, while AZM alone at the $\mathrm{MIC}_{\text {in combination }}$ inhibited the biofilm mass to a maximum of $47.1 \%$. AZM/RIF 2:1 proved clearly to be the most effective long-term prevention treatment, second only to AZM, against three out of the six bacteria tested $(p \leq 0.007)$, pointing out that the dosage of AZM in the antibiotic combination is at least fourfold lower than that of the AZM MIC and equal to the $\mathrm{AZM} \mathrm{MIC}$ in combination (Table 1). Finally, RIF alone at the $\mathrm{MIC}_{\text {in combination showed }}$ poor inhibition, with a biofilm mass reduction of between 1.1-15.2\%, with no statistically significant differences observed from untreated controls. Sub-inhibitory concentrations of AZM and RIF (MIC acquired in combination) did not seem to stimulate biofilm production. 
Table 2. Long-term antimicrobial inhibition of Rhodococcus equi biofilm formation.

\begin{tabular}{|c|c|c|c|c|c|c|}
\hline & $\operatorname{Re1}$ & $\operatorname{Re} 9$ & Re4 & $\operatorname{Re19}$ & $\operatorname{Re} 24$ & 33701 \\
\hline AZM MIC & $38.2 *, b, c, d$ & $53.6^{*, b, c, d}$ & $48.5^{*}, \mathrm{~d}$ & $49^{*}$ & 69.1 & $44.6^{*, \mathrm{~b}, \mathrm{c}, \mathrm{d}}$ \\
\hline $\mathrm{AZM} \mathrm{MIC}_{\text {in combination }}$ & $72.7^{\mathrm{a}}$ & $78.6^{a}$ & $48.5^{*} \mathrm{~d}$ & 80.7 & 81.1 & $98.9^{\mathrm{a}}$ \\
\hline RIF MIC & $78.6^{\mathrm{a}}$ & $78.3^{a}$ & $49.9 *, \mathrm{~d}$ & 84.5 & 91.7 & $97.8^{a}$ \\
\hline RIF $\mathrm{MIC}_{\text {in combination }}$ & $84.8^{a, e}$ & $94.1^{\mathrm{a}, \mathrm{e}}$ & $88.1^{\mathrm{a}, \mathrm{b}, \mathrm{c}, \mathrm{e}}$ & 95.6 & 94.1 & $98.9^{\mathrm{a}}$ \\
\hline AZM/RIF 2:1 MIC & $53.2 *, \mathrm{~d}$ & $69.4^{*, \mathrm{~d}}$ & $48.4^{*, \mathrm{~d}}$ & 72 & 84.4 & 59.4 * \\
\hline
\end{tabular}

Results are expressed as the percentage (\%) residual mass upon treatment with the minimum inhibitory concentrations (MICs) of azithromycin (AZM), rifampicin (RIF), and the AZM/RIF combination at a ratio of 2:1 with respect to untreated controls. AZM and RIF were also tested alone at the MIC value acquired in combination $\left(\mathrm{MIC}_{\text {in combination }}\right)$. Post-hoc ANOVA was applied for comparing the treatment groups at the $95 \%$ significance level. $p<0.05 *$ vs. untreated, $^{\mathbf{a}}$ vs. AZM MIC, ${ }^{\mathbf{b}}$ vs. AZM MIC in combination $^{\mathbf{c}}{ }^{\mathrm{v}}$ v. $\mathrm{RIF} \mathrm{MIC,}^{\mathrm{d}}$ vs. $\mathrm{RIF} \mathrm{MIC}_{\text {in combination }}{ }^{\mathbf{e}}$ vs. AZM/RIF 2:1 MIC.

\subsection{Kinetic Dissolution of Pre-Formed Rhodococcus equi Biofilm}

Drugs were tested for their capability to dissolve pre-formed moderate biofilms by the R. equi isolates Re1, Re4, Re9, Re19, Re24 and ATCC 33701 over time. Treatments consisted of AZM and RIF alone and AZM/RIF 2:1 at the MIC and $10 \times$ MIC. As above, to thoroughly investigate the potential boosting effect exerted by the drug combination, AZM and RIF were tested alone at the MIC value acquired in combination $\left(\mathrm{MIC}_{\text {in combination }}\right)$ and at $10 \times \mathrm{MIC}$.

The results suggest that

(1) No antimicrobial molecule, alone or in combination, is able to completely eradicate a pre-formed biofilm in the present experimental setup;

(2) The dissolution power is lower at $24 \mathrm{~h}$ post treatment (no statistically significant difference was found among treatments and the untreated control) than at longer times, particularly after $72 \mathrm{~h}$ of antibiotic application, as detailed in Supplementary Table S2;

(3) Basically, AZM alone and in combination with RIF dissolved the R. equi biofilm better than RIF monotherapy. Interestingly, AZM/RIF 2:1 at the MIC was as effective against R. equi ATCC 33701 biofilm $(p=0.011)$ as AZM alone at $10 \times$ MIC.

The antimicrobial combination at $10 \times$ MIC had a statistically significant effect, even against Re19 ( $p=0.022)$, whereas AZM and RIF alone failed at all concentrations. In turn, no significant biofilm dissolution enhancement was observed when using the drug combination against Re4, a RIF-resistant isolate, Re9, and Re24. Finally, at $72 \mathrm{~h}$ post-treatment, RIF alone at $10 \times$ MIC dissolved Re4, Re9, and Re1 biofilm $(p \leq 0.035)$ in a manner comparable to AZM and the antimicrobial combination. The results at $72 \mathrm{~h}$ post-treatment are compared in Figure 2. 

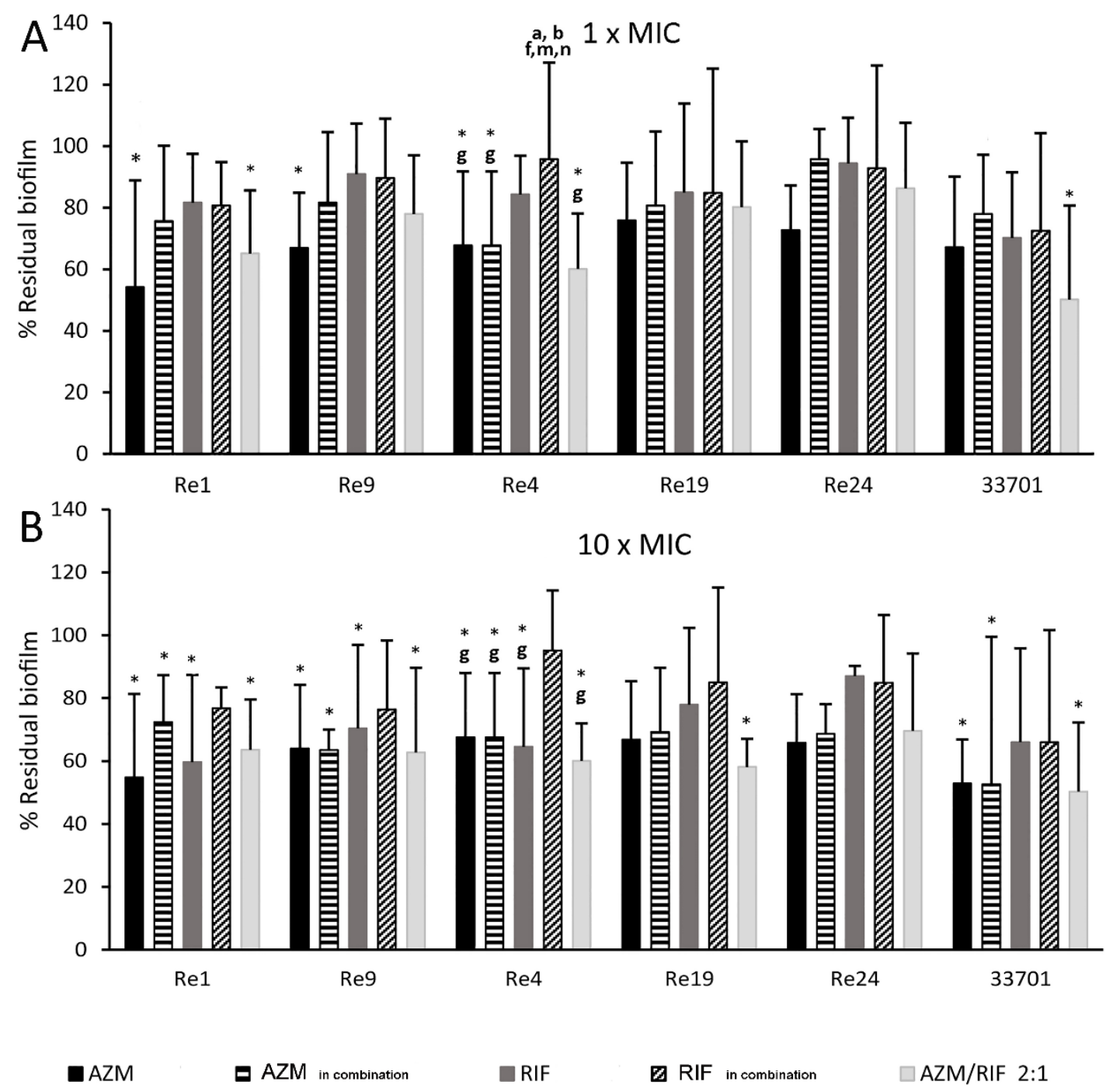

Figure 2. Biofilm dissolution at $72 \mathrm{~h}$ post treatment. Results are expressed as the percentage of biofilm residual mass \pm SD upon treatment at $(A)$ the minimum inhibitory concentration $(1 \times \mathrm{MIC})$ and (B) $10 \times$ MIC with azithromycin (AZM), rifampicin (RIF), and the AZM/RIF combination at a ratio of 2:1 with respect to untreated controls. AZM and RIF were also tested alone at the MIC value acquired in the combination ( $\mathrm{MIC}_{\text {in combination }}$ ). Statistical evaluation was performed through ANOVA with post-hoc Tukey HSD and Bonferroni tests. $p<0.05^{*}$ vs. untreated, $^{\mathbf{a}}$ vs. AZM MIC, ${ }^{\mathbf{b}}$ vs. AZM $10 \times \mathrm{MIC}^{\mathrm{c}} \mathrm{vs}^{\mathrm{v}}$ $\mathrm{AZM} \mathrm{MIC}_{\text {in combination }}{ }^{\mathbf{d}}$ vs. AZM $10 \times \mathrm{MIC}_{\text {in combination, }}{ }^{\mathbf{e}}$ vs. RIF MIC, ${ }^{\mathbf{f}}$ vs. RIF $10 \times \mathrm{MIC}, \mathbf{g}_{\text {vs. RIF }}$ $\mathrm{MIC}_{\text {in combination }}{ }^{\mathbf{h}}{ }^{\mathrm{RIF}} 10 \times \mathrm{MIC}_{\text {in combination }}{ }^{\mathbf{m}}{ }^{\mathrm{v}}$ vs. AZM/RIF 2:1 MIC, ${ }^{\mathbf{n}}$ vs. AZM/RIF 2:1 $10 \times \mathrm{MIC}$.

\subsection{Biofilm Fluorescence Measurement}

Ratio $_{\mathrm{G} / \mathrm{R}}$, a measure of the quantitative relation between green/red fluorescence, depicts the viability of sessile bacterial cells upon antimicrobial dissolution treatments. All ratios are illustrated in Figure 3. Overall, the resulted ratios reflect the measurement of biofilm mass obtained by crystal violet biofilm dissolution assay, confirming AZM and AZM/RIF 2:1, both at a concentration of $10 \times$, as the most effective, though not completely eradicating, dissolving treatments. Figure 4 shows the remarkable killing activity of AZM/RIF 2:1 at $10 \times$ MIC against sessile Re19 (F), while other antimicrobial treatments appeared to be ineffective (B-E) compared with untreated control forming biofilm aggregates. This finding portrays the $\operatorname{Ratios}_{\mathrm{G} / \mathrm{R}}$ reported in Figure 3. Additionally, while the Ratios $_{\mathrm{G} / \mathrm{R}}$ of AZM and AZM/RIF 2:1 at $10 \times$ MIC were very similar, the AZM concentrations were at least fourfold lower in the microparticle combination than for AZM alone. 
A $1 \times \mathrm{MIC}$

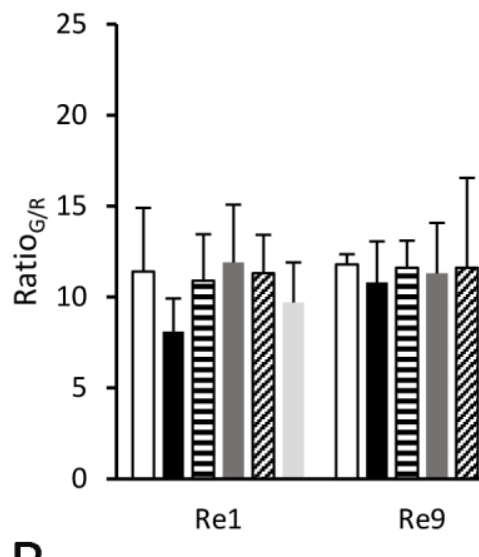

B

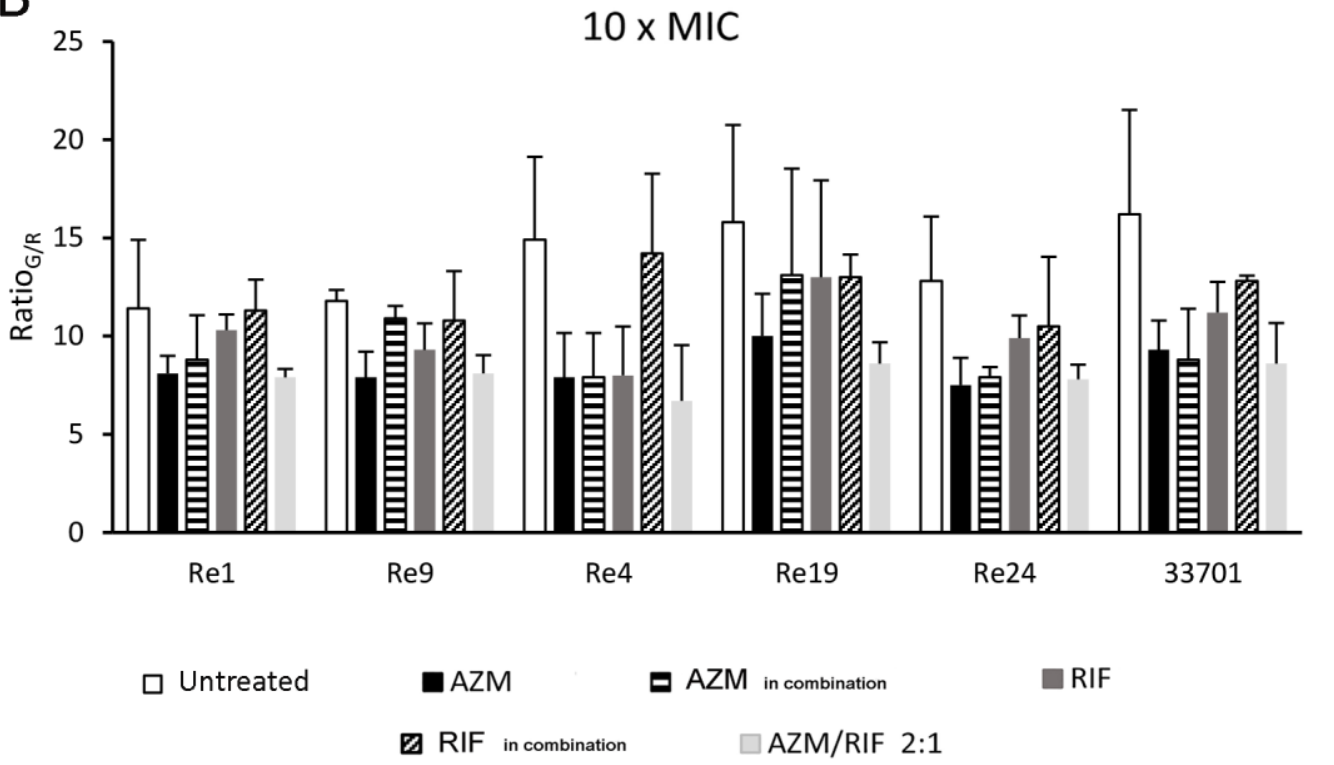

Figure 3. Quotient of the mean fluorescence intensity of green and red light emissions $\left(\mathrm{Ratio}_{\mathrm{G} / \mathrm{R}}\right)$ that emerged from the LIVE/DEAD biofilm viability assay for the evaluation of the antimicrobial dissolution capability. (A) Azithromycin (AZM) and rifampicin (RIF) were tested alone and at a 2:1 combination $(\mathrm{AZM} / \mathrm{RIF} 2: 1)$ at the minimum inhibitory concentration $(1 \times \mathrm{MIC})$ and $(\mathrm{B}) 10 \times \mathrm{MIC}$. AZM and RIF were also tested alone at the MIC value acquired in combination $\left(\mathrm{MIC}_{\mathrm{in}}\right.$ combination $)$. Green fluorescence was detected by setting the excitation/emission wavelengths at $485 / 530 \mathrm{~nm}$ while red fluorescence was set at $485 / 630 \mathrm{~nm}$. 


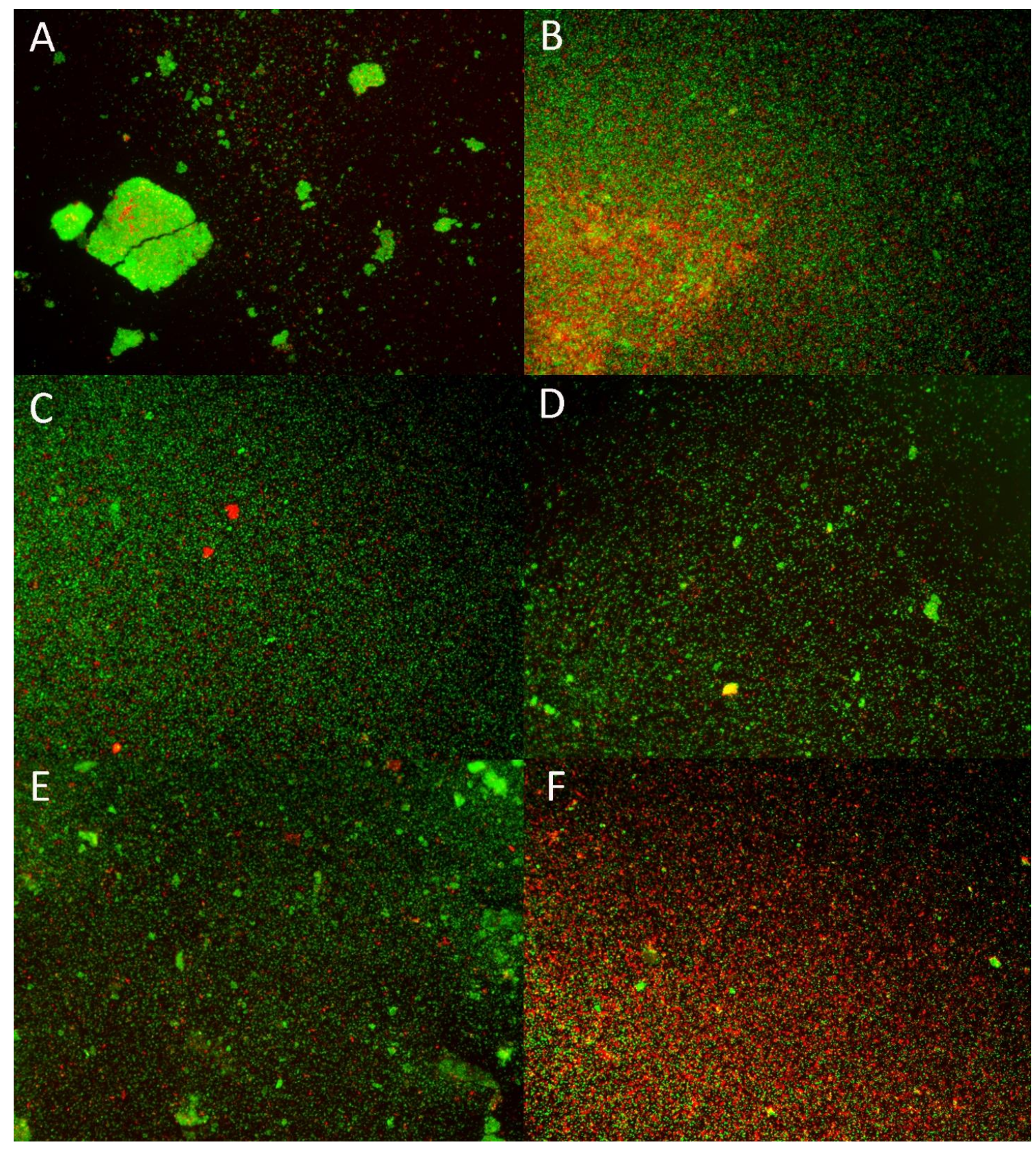

Figure 4. Fluorescent biofilm images of the Rhodococcus equi isolate Re19 captured by inverted fluorescence microscope. (A) Untreated sessile aggregates; biofilm treated for $72 \mathrm{~h}$ with (B) azithromycin (AZM) at 10-fold the minimum inhibitory concentration (MIC); (C) AZM at $10 \times$ MIC acquired in combination; (D) rifampicin (RIF) at $10 \times$ MIC; (E) RIF at $10 \times$ MIC acquired in combination; (F) AZM/RIF 2:1 combination at $10 \times$ MIC.

\subsection{Structure of Rhodococcus equi Biofilms Captured by Scanning Electron Microscope}

Further details of the biofilm structural characterization were obtained by scanning electron microscopy (SEM), which highlighted different features depending on the bacterial type observed. When not treated in vitro (Figure 5(A,1A)), R. equi ATCC 33701 formed a uniform and compact biofilm composed of a thin and minimally fibrous extracellular matrix where the typical coccobacillary shape was clearly preserved. Otherwise, coccobacilli mixed with elongated bacterial cells-evidence of a stressed condition-characterized the untreated biofilm of planktonically drug susceptible $R$. equi clinical isolates, such as Re19, as shown in Figure 5(C,1C). 

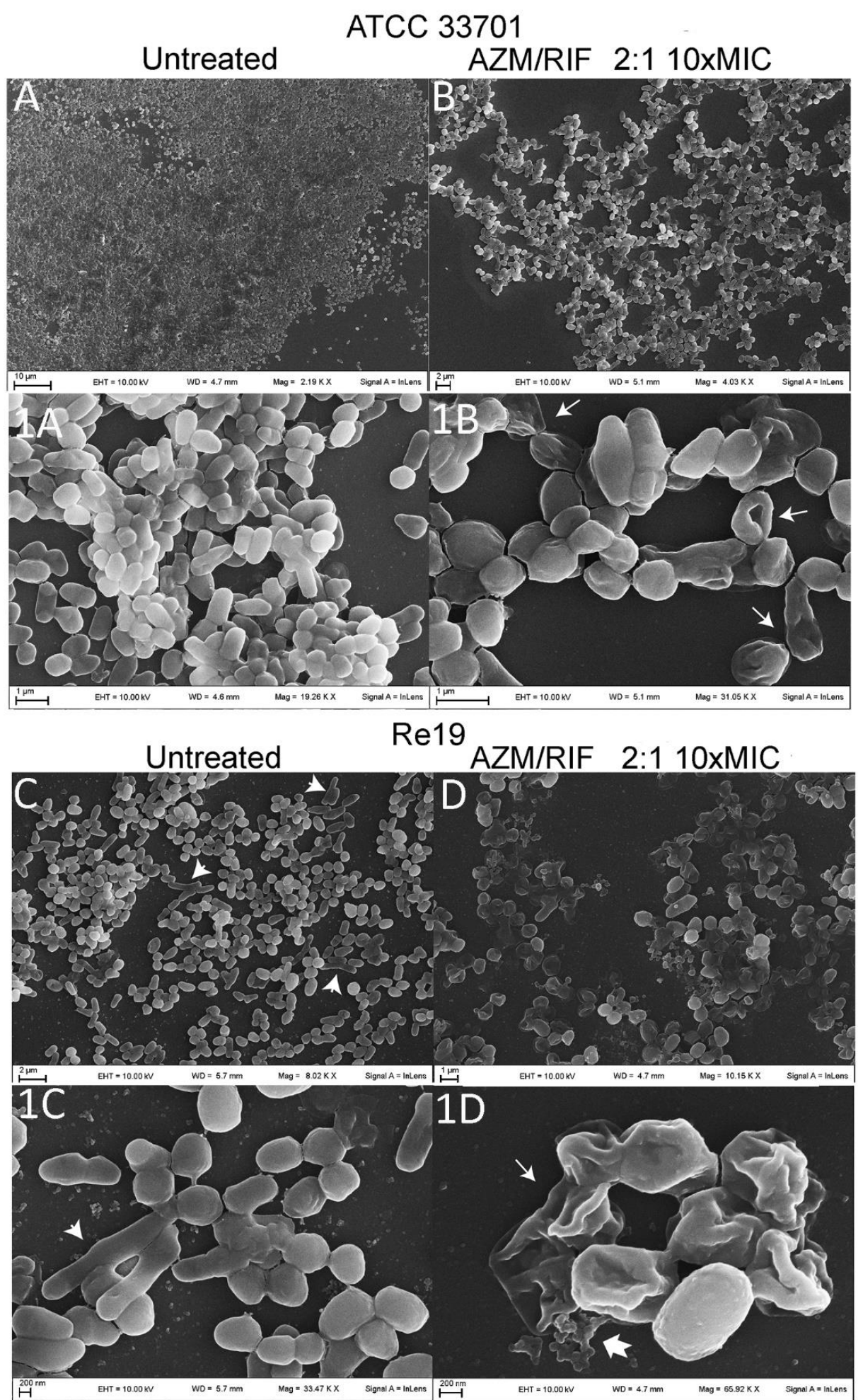

Figure 5. Scanning electron microscopy visual features upon treatment of biofilms of Rhodococcus equi ATCC 33701 (B,1B) and the clinical isolate Re19 (D,1D) with the 2:1 combination of azithromycin and rifampicin at 10-fold the minimum inhibitory concentration compared to untreated biofilms $(\mathbf{A}, \mathbf{1 A}, \mathbf{C}, \mathbf{1 C})$. Measurements were performed at $10 \mathrm{kV}$ and reported at magnifications of 2.2-65.9 kX. Short arrows indicate filamented rhodococci; long arrows indicate damaged bacteria, which appear as empty cells with intact but collapsed structures (ghost cells). The notched arrow refers to the release of intracellular vesicular components from ghost cells. 
As experimentally demonstrated above, treatments with AZM and RIF alone and in combination at ten-fold the MIC value did not totally dissolve the rhodococcal biofilms. However, the antimicrobial challenge damaged the biofilm-enclosed bacterial cells, provoking areas of biofilm detachment and craterization, causing the formation of filamented cells and collapse of bacterial walls. Collapsed cells maintained their structure although many bacteria lost their intracellular components (ghost cells). Such SEM observations are shown in Figure 5(B,1B,D,1D). The RIF-resistant isolate Re4 showed a more copious and fibrous extracellular matrix, connecting bacteria of regular shape in thick sessile aggregates (Figure 6).

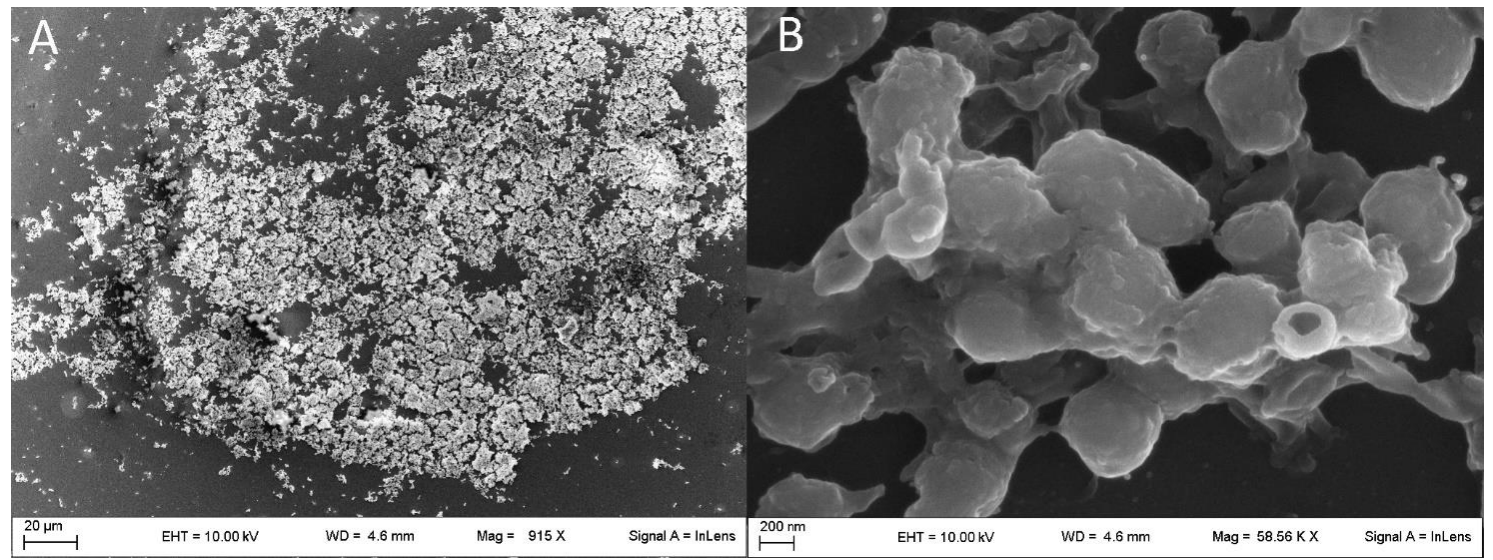

Figure 6. Scanning electron microscopy images showing untreated biofilm formed by the rifampicin-resistant Rhodococcus equi isolate Re4. Measurements were performed at $10 \mathrm{kV}$ and reported at (A) $915 \mathrm{X}$ and (B) $58.6 \mathrm{kX}$.

\section{Discussion}

\subsection{In Vitro Model of Rhodococcus equi Biofilm Growth}

Biofilm research is crucial to tackle chronic diseases that are notoriously related to bacterial communalism. Bacteria are able to persist in biotic and abiotic environments in sessile aggregates and to resist antimicrobial treatment. To date, poor literature reporting the capacity of $R$. equi to aggregate in a self-produced matrix has been available. R. equi seems to be able to produce biofilms, although some clinical isolates have been found to be non-biofilm producers at $24 \mathrm{~h}$ of incubation [20]. The kinetic crystal violet assay performed in this work demonstrated that 100\% (40/40) of the rhodococci evaluated were biofilm producers with a suggested biofilm production time of at least $48 \mathrm{~h}$, while incubation for longer than $72 \mathrm{~h}$ allowed more abundant biofilm development. This fits well with a recent study that did not find significant differences in biofilm formation among R. equi isolates at 24 and $48 \mathrm{~h}$ [19]. Interestingly, none of the strains were found to be strong biofilm producers. The reason for this may be found in either the manifested slow growth of R. equi [27] or sub-optimal in vitro growth conditions. A different scenario may occur in vivo where biotic and/or abiotic determinants might induce bacterial aggregation during the pathological and environmental life cycle of $R$. equi. It would be interesting to verify the formation of biofilm in an in vivo model, but the time span of chronic infection makes it difficult to maintain and control [28]. Therefore, in spite of the fact that compliance with in vivo observations is yet to be established, in vitro assays remain key methods for preliminarily screening microbial biofilms, allowing the adhesion capability to surrounding surfaces, the production of an extracellular matrix, and the efficacy of antimicrobial molecules to prevent or disperse biofilms to be accessed [29]. 


\subsection{Putative Pathogenic Significance of Rhodococcus equi Adhesion to Lung Alveolar Epithelium}

Surface attachment is the first necessary step for the formation of biofilm on biotic surfaces, after which the growth of the biofilm matrix makes the attachment irreversible, perpetuating the infection [21]. R. equi clinical isolates appear to be able to adhere to the pulmonary epithelium in a manner comparable to that of $S$. aureus, which is responsible for serious pneumonia in humans and animals, often by adhering to lung epithelial cells [30] and forming biofilms [31]. After inoculating $1 \times 10^{7}$ bacterial cells, the quantity of rhodococci adhering to the A549 cellular monolayer was $>10^{5}$, a bacterial dose supposedly high enough to cause severe acute pneumonia in neonatal foals, while lower infecting doses have been correlated with the development of insidious disease [32]. Despite the significant association between biofilm production and adhesion profile suggesting a direct correlation, the putative pathogenic significance of this finding remains unknown. Additionally, given that our findings are based on the use of heat-inactivated bacteria, the results from such analyses should be treated with caution, even if the difference in adhesion capability shown by heat-treated and non-heat-treated R. equi ATCC 33701 appears to be slight. Heat treatment prevents fluorescence variability due to replicative processes, and it is commonly applied on several bacterial species for surface adhesion characterization $[33,34]$. However, many questions on the surface binding mechanisms of R. equi still need clarification.

\subsection{Macrolides and Rifampicin versus Biofilm: A Controversial Issue}

Azithromycin is intracellularly effective against R. equi, infecting macrophage-converted THP-1 cells in a concentration-dependent manner [26]. There is evidence that such an activity affects long-term R. equi biofilm formation as well. Indeed, rhodococci treated preventively with anti-rhodococcosis first-line antibiotics produced a biofilm mass inversely proportional to the AZM concentration. Testing drugs at sub-inhibitory concentrations is useful for evaluating a potential stimulatory effect of antibiotics on bacterial biofilm production. Such a phenomenon was noted previously in relation to several antibiotic classes and various bacterial species [35,36]. Particularly, reports concerning the AZM influence on biofilm production are controversial. Sub-inhibitory dosage of this macrolide has the ability to retard Pseudomonas aeruginosa biofilm for up to $48 \mathrm{~h}$ [37], while the same drug is able to induce biofilm formation at lower concentrations [25]. Exploring such aspects is crucial for establishing an effective therapeutic regimen and thus preventing activation of biofilm production due to premature discontinuation of antimicrobial therapy or excessively low drug dosages at the infection site. Interestingly, we noted that sub-MIC concentrations of AZM-equal to the MIC value acquired in combination (comprised between 1/4-1/16 AZM MIC)—did not stimulate biofilm formation. On the contrary, such dosages showed various degrees of biofilm inhibition depending on the R. equi strain tested, different from what was observed on P. aeruginosa where $48 \mathrm{~h}$ exposure induced a resistant phenotype and strong biofilm formation [37]. Long-term RIF monotherapy at sub-inhibitory concentrations (RIF MIC $_{\text {in combination }}$ ) did not prevent bacterial biofilm formation. Moreover, in contrast with earlier findings against staphylococcal biofilms [38], RIF did not seem to stimulate biofilm production.

The enhancing effect of the AZM/RIF combination in inhibiting and dissolving the rhodococcal biofilm was not equally effective for all $R$. equi isolates. The recorded discrepancies were ascribed to unveiled differences among the bacteria tested. The treatment of bacterial biofilms requires tissue-penetrating antibiotics. Macrolides as well as rifamicins are listed among the molecules that better penetrate in tissues and cells [39]. It is assumed that AZM and RIF, particularly in combination, might have the potential to effectively treat rhodococcal biofilms. However, increasing the concentration of these drugs alone and in combination to ten-fold the MIC did not completely eradicate pre-formed $R$. equi biofilms. This result strengthened our hypothesis that biofilm production may occur as an antibiotic tolerance system in R. equi infections. There is limited data on the anti-sessile activity of AZM against Gram-positive bacteria, suggesting a lower anti-biofilm activity than that of clarithromycin [40], the other new generation macrolide. However, a statistically significant reduction of R. equi sessile 
aggregates emerged from our data, particularly when treated with AZM and AZM/RIF 2:1 over a prolonged period of time. These results are in good agreement with a previous study [20] which, however, employed different methodological approaches. On the other hand, the role of RIF against $R$. equi biofilm is controversial. Our data agree fairly well with those of previous studies [41] and further support the use of RIF as an adjunct treatment in place of monotherapy.

As detailed above, the LIVE/DEAD biofilm viability assay was performed to further compare the anti-sessile activity of AZM and RIF. This experimental method is based on the use of the combination of SYTO9 and propidium iodine. Therefore, it is useful for detecting the live and dead cells in regard to membrane integrity, indirectly undermined by these antimicrobial molecules. Although it has been reported that viable/dead cells might be detected incorrectly by using these combined fluorophores [42], this method enables comparative screening for antimicrobial substances and has been proven to reflect the results obtained by crystal violet biofilm dissolution assay.

\subsection{Ultramicroscopic Biofilm Phenotype-Based Assumptions}

Despite the extracellular matrix enclosing bacterial cells not dissolving completely, the ultramicroscopic details seen in the SEM revealed that highly concentrated antimicrobial treatment appears to increase the population of dead cells or cells suffering from replicative defects, which assume a distinctive collapsed and/or elongated morphological aspect. Particularly, the elongated shape is a result of the anomalous growth of bacteria that continue to elongate but do not divide. Such a phenomenon-known as "filamentation" - is a typical visual feature of stressed bacteria [43] and even provides evidence of interactions between pathogenic bacteria and their hosts [44]. Indeed, filamented bacteria characterize clinical isolates from antibiotically-treated patients [45]. Curiously, untreated biofilm of full drug susceptible isolates showed a mixed population of regular and filamented cells that were missing in in vitro untreated samples of Re4, conjecturing a less intense in vivo stress response due to the higher drug resistance. Furthermore, this bacterium demonstrated a particularly abundant production of extracellular matrix that might have played a role in the manifested RIF-resistance upon clinical treatment, while Re2-the other RIF-resistant isolate—produced biofilm weakly. Therefore, as yet, the existence and nature of a relationship between RIF resistance and the increased production of the biofilm extracellular matrix have to be ascertained.

\section{Conclusions}

As stated in the introduction, microbial biofilm research is of major value for combating chronic diseases. Very few studies have focused on the clinical and environmental importance of R. equi biofilm, in spite of the fact that R. equi disease is recognized as one of the leading subacute/chronic infectious diseases in animals and humans and the ability to form a biofilm could be an important virulence determinant for its persistence as well as its survival in the telluric environment. Despite the pathological significance of our findings and the considerably different sessile phenotypes among the field isolates observed deserving more insightful understanding, this study attempted to address some of the significant aspects of the behavior of $R$. equi in sessile form, so as to establish a starting platform for future studies elucidating the clinical relevance of $R$. equi biofilm.

\section{Materials and Methods}

\subsection{Bacteria Identification}

A total of 40 rhodococci were included in this experimental study: the ATCC 33701 and 39 R. equi isolated over the course of spontaneous equine pneumonia from 2004 to 2017 in central Italy. All sampling procedures for bacteriological examination complied with national and European regulations and, due to non-experimental-induced sampling, the present study was not subject to approval by the Ethical Committee of our Institution. Bacterial isolates were labelled from Re1 to Re39 and stored at $-20{ }^{\circ} \mathrm{C}$. After thawing, each bacterium was sub-cultured and, following the 
second passage in 5\% defibrinated sheep blood agar, DNA of suspected colonies was extracted to confirm the etiological diagnosis and the presence of the virulence plasmid. Briefly, DNA was extracted from pure plated colonies by suspending bacteria in $500 \mu \mathrm{L}$ of ultrapure water and then incubating them at $100{ }^{\circ} \mathrm{C}$ for $10 \mathrm{~min}$. The bacterial suspension was centrifugated at $14,000 \mathrm{rpm}$ for $10 \mathrm{~min}$, and $400 \mu \mathrm{L}$ of supernatant containing DNA was collected. A modified nested-PCR protocol was performed to detect the ribosomal component $16 \mathrm{~S}$ gene and virulence plasmid VapA according to published methods $[46,47]$. The $R$. equi $16 \mathrm{~S}$ gene was amplified in the first PCR reaction by using the primers f-TCGTCCGTGAAAACTTGGGGC and r-CGACCACAAGGGGGGCCGTAT, while in the nested-PCR, f-GAGGAGCGAAAGCGTGGGTA and r-TTAGCCTTGCGGCCGTACTC were used. The two pairs of PCR primers used to amplify VapA plasmid were f-GGTTCTCGTAACG CTACAATC, r-GGTTCGTCTTTCTGAAGGTT and f-TCGGAACTGCCCGAGAACAT, r-GCTCCC AGAACCGACAATGC in the first PCR reaction and nested-PCR, respectively.

\subsection{Spray-Dried Antibiotic Microparticles}

In this study, the first-line drugs AZM and RIF were tested alone and in combination to investigate their MIC against planktonic R. equi and anti-biofilm properties. To increase the drug water solubility and powder dispersibility, commercial antibiotic powders were transformed in microparticle formulations by spray-drying. The drugs were tested alone and in the exact drug molar ratio 2:1 for the AZM/RIF combination which, in a previous study [26], demonstrated a synergistic bactericidal effect against planktonic R. equi and long-term activity against a R. equi-infected intracellular model. The microparticle dry powders were produced using a Mini Spray-Dryer Model B-290 (Büchi, Milan, Italy) starting from excipient-free drug solutions at a final concentration of $2 \% \mathrm{w} / \mathrm{v}$ in acetonitrile and adopting the following conditions: inlet temperature $75^{\circ} \mathrm{C}$, air flow rate $357 \mathrm{~L} / \mathrm{h}$, feed rate $2.5 \mathrm{~mL} / \mathrm{min}$, and aspirator rate $20 \mathrm{~m}^{3} / \mathrm{h}$. The quantification of each antibiotic in the AZM/RIF combination was performed by a previously reported HPLC method [26].

\subsection{Antimicrobial Efficacy against Planktonic Bacteria}

The antimicrobial susceptibility assay was performed according to information provided by the Clinical and Laboratory Standards Institute (CLSI) [48]. A broth microdilution procedure was carried out to define the MIC values of AZM, RIF, and AZM/RIF 2:1 against all planktonic R. equi isolates over a dose range of $256-0.015 \mathrm{mg} / \mathrm{L} / \mathrm{component} \mathrm{in} \mathrm{serial} \mathrm{two-fold} \mathrm{dilutions} \mathrm{in} \mathrm{Cation-Adjusted}$ Mueller Hinton Broth (CAMHB). A dilution was prepared in CAMHB starting from a bacterial suspension at the spectrophotometric 0.5 McFarland standard to obtain a final concentration of $5 \times 10^{4} \mathrm{CFU} /$ well. Positive and negative control wells were tested in each plate and then incubated at $37^{\circ} \mathrm{C}$. The standard reading was established at $24 \mathrm{~h}$. The experiments were performed in triplicate and in three independent experiments.

\subsection{Fluorescence-Based Adhesion Assay on Pulmonary Alveolar Epithelium}

\subsubsection{Bacteria Labelling}

R. equi isolates and ATCC 33701 were grown in CAMHB at $37^{\circ} \mathrm{C}$ under aerobic conditions. The bacterial cells were resuspended in culture medium at $2 \times 10^{8} \mathrm{CFU} / \mathrm{mL}$ and centrifuged at $3500 \mathrm{rpm}$ for $10 \mathrm{~min}$. The microbial pellets were washed twice with $5 \mathrm{~mL}$ of sterile phosphate-buffered saline (PBS) and then centrifuged at $3500 \mathrm{rpm}$ for $10 \mathrm{~min}$ to resuspend the bacteria in $1 \mathrm{~mL}$ of sterile PBS. The suspended bacteria were heat-treated at $65^{\circ} \mathrm{C}$ for $1 \mathrm{~h}$. After inactivation, the cell wall integrity was confirmed by Gram-staining. To label the bacteria, $100 \mu \mathrm{L}$ of FITC was added at $0.5 \mathrm{mg} / \mathrm{mL}$ to $1 \mathrm{~mL}$ of bacterial suspension to give a final FITC concentration of $0.05 \mathrm{mg} / \mathrm{mL}$ and this was incubated at room temperature in the dark for $30 \mathrm{~min}$. The FITC-labelled bacteria were washed twice with PBS by centrifugation at $6000 \mathrm{rpm}$ for $7 \mathrm{~min}$. Finally, the bacteria were resuspended in $1 \mathrm{~mL}$ of sterile PBS and stored at $-20^{\circ} \mathrm{C}$ until further analysis. To assess the impact of the heat-treatment on bacterial adherence, 
a preliminary fluorescence-based adhesion test was performed using simultaneously heat-treated and non-heat-treated ATCC 33701. Heat-treated bacteria showed 0.1 percentage point higher adhesion than non-heat-treated ATCC 33701.

\subsubsection{Rhodococcus equi Adhesion Assay}

The A549 cell line, derived from human lung adenocarcinoma of alveolar basal epithelial cells, was obtained from the American Type Culture Collection (A549 ATCC ${ }^{\circledR}$ CCL-185, Manassas, VA, USA). Cells were maintained in RPMI 1640 medium supplemented with $10 \%$ fetal calf serum and $1 \%$ penicillin/streptomycin. One hundred microliters of a cellular suspension at $2 \times 10^{5} \mathrm{cells} / \mathrm{mL}$ was seeded into 96-well plates and incubated at $37{ }^{\circ} \mathrm{C}$ with $5 \% \mathrm{CO}_{2}$ in a humidified incubator. After $24 \mathrm{~h}$, the growth medium was removed and the cellular monolayers were washed once with $100 \mu \mathrm{L}$ of PBS. The adherence capability of each R. equi was examined by adding $1 \times 10^{7}$ of the FITC-labelled bacterial suspension on the A549 monolayers to obtain a final bacterial concentration of $1 \times 10^{8}$ bacterial cells $/ \mathrm{mL}$ in each well (MOI 1:500). At the end of $30 \mathrm{~min}$ incubation at $37^{\circ} \mathrm{C}$ and $5 \% \mathrm{CO}_{2}$ in humidified incubator, the supernatant containing non-adhered bacteria was removed and the pulmonary monolayers were washed once with $100 \mu \mathrm{L}$ of PBS. Finally, $100 \mu \mathrm{L}$ of PBS was added, and the fluorescence of adherent R. equi was read by fluorometer (Infinite M200, Tecan, Salzburg, Austria), setting the excitation at $485 \mathrm{~nm}$ and emission at $530 \mathrm{~nm}$. To measure the adherent bacteria on human alveolar epithelial monolayer, calibration curves were built for all rhodococci by plotting the fluorescence emissions of twelve serial two-fold dilutions of the FITC-labelled bacterial suspensions against the corresponding number of bacterial cells, starting from $1 \times 10^{8}$ bacteria/mL seeded on the A549 monolayer. Fluorometric tests were performed on six replicates in three independent experiments $(n=18)$. S. aureus ATCC 25923 was used as a Gram-positive model for pulmonary biofilm production [49], while sterile PBS was used as a negative control. The number of bacterial cells corresponding to the adherent fraction was derived by interpolation with the relative calibration curve. The results were expressed as the percentage of adherent bacteria compared to the initial inoculum, and the coefficient of determination $\left(\mathrm{r}^{2}\right)$ was evaluated as a measure of goodness of fit of the regression model.

\subsection{Kinetic Growth of Rhodococcus equi Biofilm and Inhibiting/Dissolving Capacity of the Antimicrobial Treatments}

Bacteria were grown in CAMHB at $37{ }^{\circ} \mathrm{C}$ to reach a spectrophotometric growth absorbance of 0.15 at $\mathrm{OD}_{600}$. To assess the growth of rhodococcal biofilms, the microorganisms were diluted 1:50 in CAMHB, and $200 \mu \mathrm{L}$ of bacterial suspension was seeded in each well of the 96-well plates and then incubated under static conditions at $37^{\circ} \mathrm{C}$ for $24,48,72$, and $96 \mathrm{~h}$. The medium was not supplemented with glucose as it is unlikely to increase the biofilm formation of $R$. equi clinical isolates [20]. At the end of each incubation time, planktonic bacteria were removed and sessile aggregates were washed with $200 \mu \mathrm{L}$ of PBS. The formed biofilms were stained by adding $100 \mu \mathrm{L}$ of a $0.4 \% \mathrm{w} / \mathrm{v}$ crystal violet solution. After washing twice with $200 \mu \mathrm{L}$ of PBS, the bound crystal violet was solubilized with $100 \mu \mathrm{L}$ of ethanol for $30 \mathrm{~min}$. The mass of sessile bacteria was measured by reading the absorbance at $570 \mathrm{~nm}$. Each measurement was carried out with six replicates for each incubation time. Results were categorized as weak, moderate, and strong biofilm compared to the OD control (ODc) according to published criteria [50]: non-biofilm producer $0 \leq \mathrm{OD} \leq \mathrm{ODc}$; weak biofilm producer ODc $<\mathrm{OD} \leq 2 \times$ ODc; moderate biofilm producer $2 \times$ ODc $<\mathrm{OD} \leq 4 \times$ ODc; strong biofilm producer $4 \times$ ODc $<$ OD. The described colorimetric biofilm assay was performed in three independent experiments $(n=18)$. Subsequently, AZM, RIF, and their combination at a ratio of 2:1 were assayed to evaluate their ability to inhibit and dissolve R. equi biofilm. For biofilm inhibition assay, bacterial suspensions at $\mathrm{OD}_{600} 0.15$ were diluted 1:25 in CAMHB and $100 \mu \mathrm{L}$ was incubated together with $100 \mu \mathrm{L}$ of the treatments in 96 -well flat plates at $37^{\circ} \mathrm{C}$ for $96 \mathrm{~h}$. To verify the long-term biofilm-dissolving effect of the drugs, $96 \mathrm{~h}$-old biofilms were treated with $200 \mu \mathrm{L}$ of the treatments and incubated at $37^{\circ} \mathrm{C}$ for a further 24,48 , and $72 \mathrm{~h}$. At the end of the incubation period, planktonic 
bacteria were removed and the formed biofilms were stained as described above. The mass of biofilm was measured by comparing the absorbance values of the treated bacteria versus untreated controls and expressed as the percentage residual mass of the untreated control. The biofilm inhibition and dissolution tests were performed, each with four replicates in four independent experiments $(n=16)$.

\subsection{Morphological Characterization of Rhodococcus equi Biofilm}

\subsubsection{LIVE/DEAD Biofilm Viability Assay and Fluorescence Microscopy}

Rhodococcal biofilms were stained in triplicate with LIVE/DEAD BacLight Bacterial Viability Kit (ThermoFisher Scientific, Milan, Italy), consisting of the fluorescent nucleic acid stains SYTO9 and propidium iodine when carrying out biofilm dissolution assay. As above, at the end of the $72 \mathrm{~h}$ treatment period, planktonic bacteria were removed and the formed biofilms were washed with $200 \mu \mathrm{L}$ of PBS. Biofilms were stained with $200 \mu \mathrm{L}$ of LIVE/DEAD solution, prepared following the manufacturer's instructions for $15 \mathrm{~min}$ at room temperature in the dark. After carefully removing floating bacteria, fluorescent biofilms were washed with $200 \mu \mathrm{L}$ of PBS. Finally, $100 \mu \mathrm{L}$ of PBS was added and the fluorescence was measured by a fluorometer. Green fluorescence was detected by setting the excitation/emission wavelengths at $485 / 530 \mathrm{~nm}$, while red fluorescence was set at $485 / 630 \mathrm{~nm}$. Experiments were assayed in triplicate and repeated twice. Data were analyzed by dividing the mean fluorescence intensity of green light by red light emissions $\left(\operatorname{Ratio}_{\mathrm{G} / \mathrm{R}}\right)$. Fluorescent image acquisition was performed by inverted fluorescent microscope using a Nikon Eclipse TF2000-S microscope (Nikon, Milan, Italy).

\subsubsection{Scanning Electron Microscopy}

SEM was applied to image treated and untreated biofilms of R. equi ATCC 33701 and field isolates by using a FEG LEO 1525 high resolution microscope equipped with a GEMINI column (ZEISS, Jena, Germany). Biofilms were grown on sterile round glass slides at the bottom of 24-well plates for $96 \mathrm{~h}$. After removing planktonic bacteria, biofilms were treated with AZM and RIF alone and in a 2:1 combination at 1 and $10 \times$ MIC for $72 \mathrm{~h}$, as described above. At the end of the incubation period, biofilms were washed with PBS and fixed with $2.5 \% \mathrm{w} / \mathrm{v}$ glutaraldehyde for $1 \mathrm{~h}$ and dehydrated with ethyl alcohol at $50 \%$ for $10 \mathrm{~min}, 85 \%$ for $10 \mathrm{~min}, 95 \%$ for $15 \mathrm{~min}$, and $100 \%$ absolute twice for $10 \mathrm{~min}$ each. After drying, the biofilms on the round glass slides were placed onto an aluminum stub covered with carbon tape and coated with chromium at $20 \mathrm{~mA}$ for $18 \mathrm{~s}$ prior to imaging. Measurements were performed at $5 \mathrm{kV}$ and images are reported at magnifications between $915 \mathrm{X}$ and $65.9 \mathrm{kX}$.

\subsection{Statistical Analysis}

Since histogram evaluation showed asymmetric distribution of bacterial adhesion data, the non-parametric Spearman rho test was applied to measure the correlation between the adhesion profile and biofilm produced at 24, 48, 72, and $96 \mathrm{~h}$. The ANOVA test with post-hoc Tukey HSD and Bonferroni correction was applied to compare treatments in the colorimetric biofilm inhibition and dissolution assays as biological replicates, assessing the biofilm residual masses upon treatment. All analyses were performed at $95 \%$ significance level.

Supplementary Materials: The following are available online at http://www.mdpi.com/2076-0817/8/4/284/s1, Table S1: Bacterial adhesion to A549 lung alveolar monolayers and coefficients of determination $\mathrm{r}^{2}$ of the calibration curves obtained for all rhodococci tested., Table S2: Percentage biofilm residual mass after 24, 48 and $72 \mathrm{~h}$ dissolving treatment with the minimum inhibitory concentration (MIC) and 10xMIC of azithromycin (AZM), rifampicin (RIF) and AZM/RIF combination at a ratio of 2:1.

Author Contributions: Conceptualization, E.R., M.L.M., S.G. and D.P.; Data curation, E.R. and D.P.; Formal analysis, E.R. and D.P.; Funding acquisition, M.L.M., F.P., M.C. and D.P.; Investigation, E.R.; Methodology, E.R., S.G. and D.P.; Project administration, M.C. and D.P.; Resources, M.L.M., S.G., F.P., M.C. and D.P.; Supervision, M.L.M., S.G. and D.P.; Validation, M.L.M., S.G., F.P., M.C. and D.P.; Writing-original draft, E.R.; Writing一review \& editing, M.L.M., S.G., F.P., M.C. and D.P. 
Funding: This research did not receive any specific grant from funding agencies in the public, commercial, or not-for-profit sectors.

Acknowledgments: We gratefully acknowledge Luisa Pascucci for her assistance with SEM analysis.

Conflicts of Interest: The authors declare no conflict of interest.

\section{References}

1. Costerton, W.; Veeh, R.; Shirtliff, M.; Pasmore, M.; Post, C.; Ehrlich, G. The application of biofilm science to the study and control of chronic bacterial infections. J. Clin. Investig. 2003, 112, 1466-1477. [CrossRef]

2. Ojha, A.K.; Baughn, A.D.; Sambandan, D.; Hsu, T.; Trivelli, X.; Guerardel, Y.; Alahari, A.; Kremer, L.; Jacobs, W.R.; Hatfull, G.F. Growth of Mycobacterium tuberculosis biofilms containing free mycolic acids and harbouring drug-tolerant bacteria. Mol. Microbiol. 2008, 69, 164-174. [CrossRef] [PubMed]

3. Al Akhrass, F.; Al Wohoush, I.; Chaftari, A.-M.; Reitzel, R.; Jiang, Y.; Ghannoum, M.; Tarrand, J.; Hachem, R.; Raad, I. Rhodococcus bacteremia in cancer patients is mostly catheter related and associated with biofilm formation. PLoS ONE 2012, 7, e32945. [CrossRef] [PubMed]

4. Johnson, D.H.; Cunha, B.A. Rhodococcus equi pneumonia. Semin. Respir. Infect. 1997, 12, 57-60. [PubMed]

5. Asoh, N.; Watanabe, H.; Fines-Guyon, M.; Watanabe, K.; Oishi, K.; Kositsakulchai, W.; Sanchai, T.; Kunsuikmengrai, K.; Kahintapong, S.; Khantawa, B.; et al. Emergence of rifampin-resistant Rhodococcus equi with several types of mutations in the rpoB gene among AIDS patients in northern Thailand. J. Clin. Microbiol. 2003, 41, 2337-2340. [CrossRef]

6. Gray, K.J.; French, N.; Lugada, E.; Watera, C.; Gilks, C.F. Rhodococcus equi and HIV-1 infection in Uganda. J. Infect. 2000, 41, 227-231. [CrossRef]

7. Herath, S.; Lewis, C.; Nisbet, M. Increasing awareness of Rhodococcus equi pulmonary infection in the immunocompetent adult: A rare infection with poor prognosis. N. Z. Med. J. 2013, 126, 165-174. [PubMed]

8. Hulsewé-Evers, H.P.; Jansveld, C.A.; Jansz, A.R.; Schneider, M.M.; Bravenboer, B. HIV-infected patient with a Rhodococcus equi pneumonia. Neth. J. Med. 2000, 57, 25-29. [CrossRef]

9. Khan, M.Y.; Ali, S.; Baqi, S. Rhodococcus equi pneumonia in a live related renal transplant recipient. J. Pak. Med. Assoc. 2013, 63, 635-638.

10. Mizuno, Y.; Sato, F.; Sakamoto, M.; Yoshikawa, K.; Yoshida, M.; Shiba, K.; Onodera, S.; Matsuura, R.; Takai, S. VapB-positive Rhodococcus equi infection in an HIV-infected patient in Japan. J. Infect. Chemother. 2005, 11, 37-40. [CrossRef]

11. Weinstock, D.M.; Brown, A.E. Rhodococcus equi: An emerging pathogen. Clin. Infect. Dis. 2002, 34, $1379-1385$. [CrossRef] [PubMed]

12. von Bargen, K.; Haas, A. Molecular and infection biology of the horse pathogen Rhodococcus equi. FEMS Microbiol. Rev. 2009, 33, 870-891. [CrossRef] [PubMed]

13. Muscatello, G.; Gilkerson, J.R.; Browning, G.F. Detection of virulent Rhodococcus equi in exhaled air samples from naturally infected foals. J. Clin. Microbiol. 2009, 47, 734-737. [CrossRef] [PubMed]

14. Stewart, A.; Sowden, D.; Caffery, M.; Bint, M.; Broom, J. Rhodococcus equi infection: A diverse spectrum of disease. IDCases 2019, 15, e00487. [CrossRef] [PubMed]

15. Lin, W.V.; Kruse, R.L.; Yang, K.; Musher, D.M. Diagnosis and Management of Pulmonary Infection due to Rhodococcus equi. Clin. Microbiol. Infect. 2019, 25, 310-315. [CrossRef]

16. Witkowski, L.; Rzewuska, M.; Takai, S.; Kizerwetter-Świda, M.; Kita, J. Molecular epidemiology of Rhodococcus equi in slaughtered swine, cattle and horses in Poland. BMC Microbiol. 2016, 16, 98. [CrossRef] [PubMed]

17. Ocampo-Sosa, A.A.; Lewis, D.A.; Navas, J.; Quigley, F.; Callejo, R.; Scortti, M.; Leadon, D.P.; Fogarty, U.; Vázquez-Boland, J.A. Molecular Epidemiology of Rhodococcus equi Based on traA, vapA, and vapB Virulence Plasmid Markers. J. Infect. Dis. 2007, 196, 763-769. [CrossRef]

18. Vechi, H.T.; de Oliveira, E.T.G.; de Freitas, M.R.; Rossi, F.; de Britto, M.H.M.F.; Alves, M.D.M. Chronic cavitary pneumonia by Rhodococcus equi in a highly prevalent tuberculosis country: A diagnosis challenge. Rev. Inst. Med. Trop. Sao Paulo 2018, 60, e74. [CrossRef]

19. Bujold, A.R.; Lani, N.R.; Sanz, M.G. Strain-to-strain variation of Rhodococcus equi growth and biofilm formation in vitro. BMC Res. Notes 2019, 12, 519. [CrossRef] 
20. Gressler, L.T.; de Vargas, A.C.; da Costa, M.M.; Sutili, F.J.; Schwab, M.; Pereira, D.I.B.; Sangioni, L.A.; de A. Botton, S. Biofilm formation by Rhodococcus equi and putative association with macrolide resistance. Pesqui. Veterinária Bras. 2015, 35, 835-841. [CrossRef]

21. Petrova, O.E.; Sauer, K. Sticky situations: Key components that control bacterial surface attachment. J. Bacteriol. 2012, 194, 2413-2425. [CrossRef] [PubMed]

22. Orme, I.M. A new unifying theory of the pathogenesis of tuberculosis. Tuberc. (Edinb) 2014, 94, 8-14. [CrossRef] [PubMed]

23. Giguère, S. Treatment of Infections Caused by Rhodococcus equi. Vet. Clin. North Am. Equine Pr. 2017, 33, 67-85. [CrossRef] [PubMed]

24. Polonio, R.E.; Mermel, L.A.; Paquette, G.E.; Sperry, J.F. Eradication of biofilm-forming Staphylococcus epidermidis (RP62A) by a combination of sodium salicylate and vancomycin. Antimicrob. Agents Chemother. 2001, 45, 3262-3266. [CrossRef] [PubMed]

25. Aka, S.T.; Haji, S.H. Sub-MIC of antibiotics induced biofilm formation of Pseudomonas aeruginosa in the presence of chlorhexidine. Braz. J. Microbiol. 2015, 46, 149-154. [CrossRef]

26. Rampacci, E.; Marenzoni, M.L.; Chiaradia, E.; Passamonti, F.; Ricci, M.; Pepe, M.; Coletti, M.; Giovagnoli, S. In vitro performances of novel co-spray-dried azithromycin/rifampicin microparticles for Rhodococcus equi disease treatment. Sci. Rep. 2018, 8, 12149. [CrossRef]

27. Prescott, J.F. Rhodococcus equi: An animal and human pathogen. Clin. Microbiol. Rev. 1991, 4, $20-34$. [CrossRef]

28. Bjarnsholt, T.; Alhede, M.; Alhede, M.; Eickhardt-Sørensen, S.R.; Moser, C.; Kühl, M.; Jensen, P.Ø.; Høiby, N. The in vivo biofilm. Trends Microbiol. 2013, 21, 466-474. [CrossRef]

29. Lebeaux, D.; Chauhan, A.; Rendueles, O.; Beloin, C. From in vitro to in vivo Models of Bacterial Biofilm-Related Infections. Pathogens 2013, 2, 288-356. [CrossRef]

30. Sadowska, B.; Bonar, A.; von Eiff, C.; Proctor, R.A.; Chmiela, M.; Rudnicka, W.; Róźalska, B. Characteristics of Staphylococcus aureus, isolated from airways of cystic fibrosis patients, and their small colony variants. FEMS Immunol. Med. Microbiol. 2002, 32, 191-197. [CrossRef]

31. Boisvert, A.-A.; Cheng, M.P.; Sheppard, D.C.; Nguyen, D. Microbial Biofilms in Pulmonary and Critical Care Diseases. Ann. Am. Thorac. Soc. 2016, 13, 1615-1623. [CrossRef] [PubMed]

32. Sanz, M.; Loynachan, A.; Sun, L.; Oliveira, A.; Breheny, P.; Horohov, D.W. The effect of bacterial dose and foal age at challenge on Rhodococcus equi infection. Vet. Microbiol. 2013, 167, 623-631. [CrossRef] [PubMed]

33. Huesca, M.; Peralta, R.; Sauder, D.N.; Simor, A.E.; McGavin, M.J. Adhesion and virulence properties of epidemic Canadian methicillin-resistant Staphylococcus aureus strain 1: Identification of novel adhesion functions associated with plasmin-sensitive surface protein. J. Infect. Dis. 2002, 185, 1285-1296. [CrossRef] [PubMed]

34. Piqué, N.; Berlanga, M.; Miñana-Galbis, D. Health Benefits of Heat-Killed (Tyndallized) Probiotics: An Overview. Int. J. Mol. Sci. 2019, 20, 2534. [CrossRef] [PubMed]

35. Nucleo, E.; Steffanoni, L.; Fugazza, G.; Migliavacca, R.; Giacobone, E.; Navarra, A.; Pagani, L.; Landini, P. Growth in glucose-based medium and exposure to subinhibitory concentrations of imipenem induce biofilm formation in a multidrug-resistant clinical isolate of Acinetobacter baumannii. BMC Microbiol. 2009, 9, 270. [CrossRef]

36. Hoffman, L.R.; D'Argenio, D.A.; MacCoss, M.J.; Zhang, Z.; Jones, R.A.; Miller, S.I. Aminoglycoside antibiotics induce bacterial biofilm formation. Nature 2005, 436, 1171-1175. [CrossRef]

37. Gillis, R.J.; Iglewski, B.H. Azithromycin Retards Pseudomonas aeruginosa Biofilm Formation. J. Clin. Microbiol. 2004, 42, 5842-5845. [CrossRef]

38. Lima-e-Silva, A.A.; Silva-Filho, R.G.; Fernandes, H.M.Z.; Saramago, C.S.M.; Viana, A.S.; Souza, M.J.; Nogueira, E.M. Sub-Inhibitory Concentrations of Rifampicin Strongly Stimulated Biofilm Production in S. aureus. Open Microbiol. J. 2017, 11, 142-151. [CrossRef]

39. Wu, H.; Moser, C.; Wang, H.-Z.; Høiby, N.; Song, Z.-J. Strategies for combating bacterial biofilm infections. Int. J. Oral Sci. 2015, 7, 1-7. [CrossRef]

40. Presterl, E.; Hajdu, S.; Lassnigg, A.M.; Hirschl, A.M.; Holinka, J.; Graninger, W. Effects of Azithromycin in Combination with Vancomycin, Daptomycin, Fosfomycin, Tigecycline, and Ceftriaxone on Staphylococcus epidermidis Biofilms. Antimicrob. Agents Chemother. 2009, 53, 3205-3210. [CrossRef] 
41. Croes, S.; Beisser, P.S.; Neef, C.; Bruggeman, C.A.; Stobberingh, E.E. Unpredictable Effects of Rifampin as an Adjunctive Agent in Elimination of Rifampin-Susceptible and -Resistant Staphylococcus aureus Strains Grown in Biofilms. Antimicrob. Agents Chemother. 2010, 54, 3907-3912. [CrossRef] [PubMed]

42. Stiefel, P.; Schmidt-Emrich, S.; Maniura-Weber, K.; Ren, Q. Critical aspects of using bacterial cell viability assays with the fluorophores SYTO9 and propidium iodide. BMC Microbiol. 2015, 15, 36. [CrossRef] [PubMed]

43. Díaz-Visurraga, J.; Cárdenas, G.; García, A. Morphological changes induced in bacteria as evaluated by electron microscopy. In Microscopy: Science, Technology, Applications and Education; Méndez-Vilas, A., Díaz, J., Eds.; 4th series; Formatex Microscopy: Badajoz, Spain, 2010; pp. 307-315.

44. Justice, S.S.; Hunstad, D.A.; Cegelski, L.; Hultgren, S.J. Morphological plasticity as a bacterial survival strategy. Nat. Rev. Microbiol. 2008, 6, 162-168. [CrossRef] [PubMed]

45. Giovagnoli, S.; Pietrella, D.; Barberini, L.; Santi, C.; Carotti, A.; di Michele, A.; Ricci, M. Reshaping antibiotics through hydrophobic drug-bile acid ionic complexation enhances activity against Staphylococcus aureus biofilms. Int. J. Pharm. 2017, 528, 144-162. [CrossRef]

46. Sellon, D.C.; Besser, T.E.; Vivrette, S.L.; McConnico, R.S. Comparison of nucleic acid amplification, serology, and microbiologic culture for diagnosis of Rhodococcus equi pneumonia in foals. J. Clin. Microbiol. 2001, 39, 1289-1293. [CrossRef]

47. Marenzoni, M.L.; Coppola, G.; Cappelli, K.; Capomaccio, S.; Felicetti, M.; Cercone, M.; Tamantini, C.; Genga, E.; Lepri, E.; Coletti, M.; et al. Development of a nested PCR for the diagnosis of Rhodococcus equi infection. Ippologia 2011, 22, 13-18.

48. Clinical and Laboratory Standards Institute. Susceptibility Testing of Mycobacteria, Nocardiae, and Other Aerobic Actinomycetes, 2nd ed.; CLSI: Wayne, PA, USA, 2011.

49. Hirschhausen, N.; Block, D.; Bianconi, I.; Bragonzi, A.; Birtel, J.; Lee, J.C.; Dübbers, A.; Küster, P.; Kahl, J.; Peters, G.; et al. Extended Staphylococcus aureus persistence in cystic fibrosis is associated with bacterial adaptation. Int. J. Med. Microbiol. 2013, 303, 685-692. [CrossRef]

50. Stepanovic, S.; Vukovic, D.; Dakic, I.; Savic, B.; Svabic-Vlahovic, M. A modified microtiter-plate test for quantification of staphylococcal biofilm formation. J. Microbiol. Methods 2000, 40, 175-179. [CrossRef]

(C) 2019 by the authors. Licensee MDPI, Basel, Switzerland. This article is an open access article distributed under the terms and conditions of the Creative Commons Attribution (CC BY) license (http://creativecommons.org/licenses/by/4.0/). 